\title{
Journal of FisheriesSciences.com
}

\author{
E-ISSN 1307-234X
}

(C) 2018 Www.fisheriessciences.com

Research Article

\section{Toxic Effects of Water Pollution on Two Bio-indicators of Aquatic Resources of Asa River, Nigeria}

\section{Ogundiran M.A. and Fawole O.O.}

Department of Pure and Applied Biology, Faculty of Pure and Applied Sciences, Ladoke Akintola University of Technology, Ogbomoso, Nigeria Received: 24.04.2018 / Accepted: 17.05.2018 / Published online: 30.05.2018

\begin{abstract}
:
Fishes are largely used for the assessment of aquatic environment quality and are accepted as bioindicators of environmental pollution. Studies of Hematology provide useful information on the effects of the external environment on the internal physiology of fish. This present study aims to evaluate the variation in blood parameters of Clarias buthupogon and Heterobranchus longifilis. Different hematological and biochemical indices like red blood corpuscles (RBC), white blood corpuscles (WBC), haemoglobin (Hb\%), haematocrite (PCV) and erythrocyte indices like mean corpuscular volume (MCV), mean corpuscular haemoglobin $(\mathrm{MCH})$, mean corpuscular haemoglobin concentration (MCHC), total Protein, glucose, cholesterol, albumin, chloride, hydrogen carbonate, potassium, sodium and calcium were determined using standard laboratory procedures. Generally, haematological indices were significantly $(\mathrm{p}<0.05)$ low in the dry season compared to rainy season. Plasma protein was low in the dry season $(4.56 \pm 1.45 \mathrm{~g} / \mathrm{dl})$ and slightly high during rainy season $(11.12 \pm 19.72 \mathrm{~g} / \mathrm{dl})$ and downstream A $(3.73 \pm 1.37 \mathrm{~g} / \mathrm{dl})$ to downstream B $(11.94 \pm 19.40 \mathrm{~g} / \mathrm{dl})$. Glucose level was high at downstream A $(156 \pm 12.12 \mathrm{~g} / \mathrm{dl})$ and in the dry season $(150.94 \pm 12.53 \mathrm{~g} / \mathrm{dl})$ while there was no significant correlation between the value of albumin $(\mathrm{p}<0.05)$ but there were significant correlations $(\mathrm{p}<0.05)$ for other biochemical indices for both sampling sites and seasons. Observation of blood parameters allows the most rapid detection of changes in fish after the exposure to xenobiotics. It can be concluded that hematological and biochemical parameters could be ranked as possible biomarkers of pollution.
\end{abstract}

Keywords: Toxic effects; Pollution; Bio-indicator; Aquatic; Asa river 


\section{Introduction}

Influx of unwanted substances into our water bodies cause changes in the physical, chemical and biological characteristics of the aquatic system which lead to ecological imbalance. The industrial effluents contribute a lot to water pollution forming a threat to aquatic plants and animals (Ramona et al., 2001). A greater part of the pollutants exhibit biomagnification and bioaccumulation capabilities with a broad spectrum of impacts, and stresses on aquatic organisms (Censi et al., 2006). This leads to a steady decline in the aquatic flora and fauna, particularly fishes. Ogundiran et al., (2007) reported that the fishes are more susceptible to stress than many other animals because of their intimate dependence upon their surrounding environment. Aquatic organisms, like fish, accumulate pollutants directly from contaminated water and indirectly through the food chain (Riba et al., 2004 and Ashraf, 2005). Once the toxicant enters the body of the fish they may affect the organs leading to physiological and pathological disorders (Ogundiran et al., 2009)

The hematological index can be used effectively to monitoring the response of fishes to various toxicants reflecting the ecological status of the habitat and is a common method to determine the sub-lethal effects of the pollutant. Therefore, blood parameters are used as indicators for predicting the health whereabouts and toxicological symptoms of organisms, particularly fishes (Pimpao, 2007). Rios et al. (2002) reported that the hematological parameters in fish are influenced by factors such as sex, reproductive stage, age, size and health and the external factors such as seasonal dynamics, water temperature, environmental quality, food and stress. In another study, Elahee and Bhagwant (2007) reported the hematological and gill histopathological parameters of three tropical fish species from a polluted lagoon on the west coast of Mauritius and likened the changes in blood parameters would be a sign of fish physiological response against environmental stresses (Vosyliene, 1996).

Haematological studies in fishes have assumed greater importance because these parameters were used as an efficient and sensitive index to monitor the physiological and pathological changes induced by natural or anthropogenic factors such as bacterial or fungal infection or pollution of water resources (Blaxhall, 1972). Blood parameters therefore considered as a useful tool in diagnosing the functional status of the body in response to various stressors (Houston and Carlile, 1997). The toxicants are stressors which are accumulated in the fish through the food chain or absorption through the general body surface and severely affect the life supporting system at molecular and biochemical levels. Pollutants generally produce relatively quick changes in hematological characteristics of fish (Rizkalla et al., 1999). Therefore, the haematological studies are a potential tool to analyse the effect of toxicants on various target organs of fish in laboratory experiments and in field investigations (Kori Siakpere et al., 2005). In view of the above, this work aimed at evaluating the impact of water pollution on the haematological and biochemical indices of C. buthupogon and H. longifilis collected from Asa River, Nigeria.

\section{Materials and Methods}

\section{Fish collection}

Live specimens of healthy Clarias buthupogon and Heterobranchus longifilis were collected from the downstream portion of the river with the help of local fishermen. Fishes of mixed sexes (smallest specimen caught for C. buthupogon had a total length of $11.4 \mathrm{~cm}$, standard length of $8.6 \mathrm{~cm}$ and a total weight of $5.0 \mathrm{~g}$ while the biggest specimen caught had a total length of $48.5 \mathrm{~cm}$, standard length of $43.2 \mathrm{~cm}$ and a total weight of $50 \mathrm{~g}$. For H. Longifilis, the smallest specimen caught had a total length of $23.4 \mathrm{~cm}$, standard length of $20.0 \mathrm{~cm}$ and a total weight of $80 \mathrm{~g}$, and the biggest specimen had a total length of $65.3 \mathrm{~cm}$, standard length of $62.8 \mathrm{~cm}$ and a total weight of $2,700 \mathrm{~g}$ ) were collected and the blood of fishes were collected immediately on site from the caudal peduncle (Kocabatmaz and Ekngen, 1982) in EDTA (ethylene diamine tetraacetate) coated tubes during the morning hours at a fixed time to avoid diurnal variation in the blood parameters for further analysis. The total erythrocytes count and leucocytes count were enumerated in an improved Neubaeur hemocytometer using Hayem's diluting fluid and Turk's fluid, respectively in light microscope. Hemoglobin $(\mathrm{Hb})$ concentration was measured by Sahlis method. The microhematocrit method was used to determine the hematocrit (PCV). The hematological indices: such as mean corpuscular volume (MCV), mean corpuscular hemoglobin $(\mathrm{MCH})$ and mean corpuscular hemoglobin concentration (MCHC) were calculated from the equation given by the Dacie and Lewis (2001). The biochemical analysis was done by simply centrifuge blood sample at $4000 \mathrm{rpm}$ for $20 \mathrm{~min}$ (centrifuge; Universal 320 $\mathrm{R}$ (Hettich Zentrifugen)) to separate the plasma and analyzed. The separated serum was then analysed for total protein (TP) and blood enzymes such as Lactate dehydrogenase (LD), Alkaline phosphatase (ALP), Alkaline transeaminase (ALT) and Aspartate. transeaminase (AST). An automatic blood enzyme analyzer (Hitachi 704) was used for the following determinations: Total protein (TP,g $\left.1^{-1}\right)$, Lactate dehydrogenase ( $\left.\mathrm{LD}, \mu \mathrm{kat}^{-1}\right)$, Alkaline

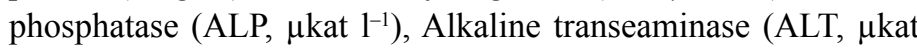
$\mathrm{1}^{-1}$ ) and Aspartate transeaminase (AST, $\mu \mathrm{kat}^{1-1}$ ). The apparatus is based upon dry chemical technology and colorimetric reaction. Kits obtained PLIVALachema and DIALAB, were used for the determination of all serum indices. $\mathrm{Na}, \mathrm{K}, \mathrm{Ca}, \mathrm{P}, \mathrm{Cl}$ were measured by kits (Lot numbers of kits; E485, F133, F108, E485 and E389, respectively (purchased Thermo SCIENTIFIC) using Konelab Prime 60I. The hematological and biochemical parameters are expressed in international units (SI).

\section{Results and Discussion}

The results of haematological parameters are presented in Figures 1-4. The results revealed that the $\mathrm{PCV}, \mathrm{Hb}$ and $\mathrm{RBC}$ counts in fishes showed significantly higher value during rainy season 


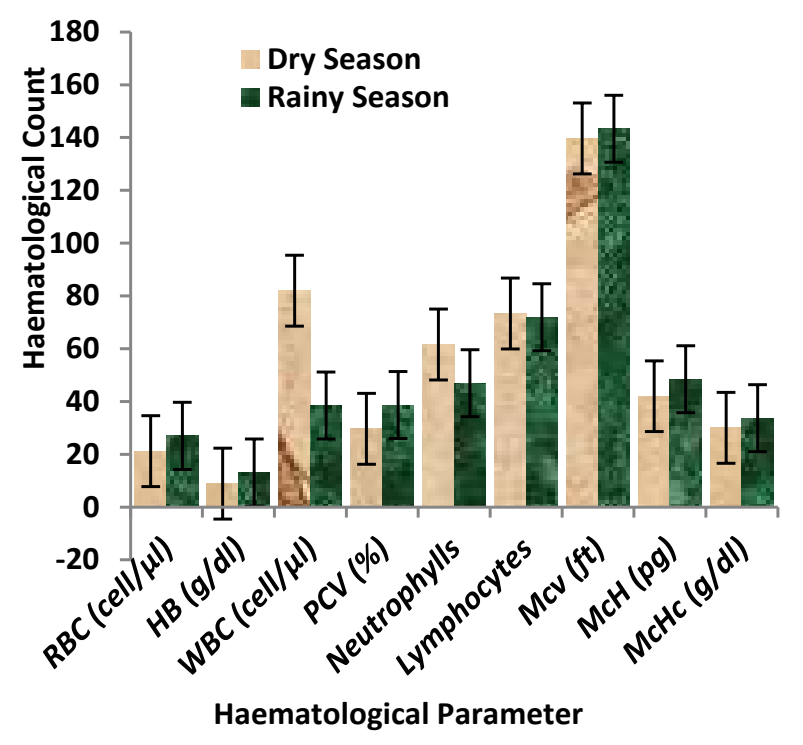

Figure 1: Seasonal variation in the haematological profile of $C$. buthupogon from Asa River.

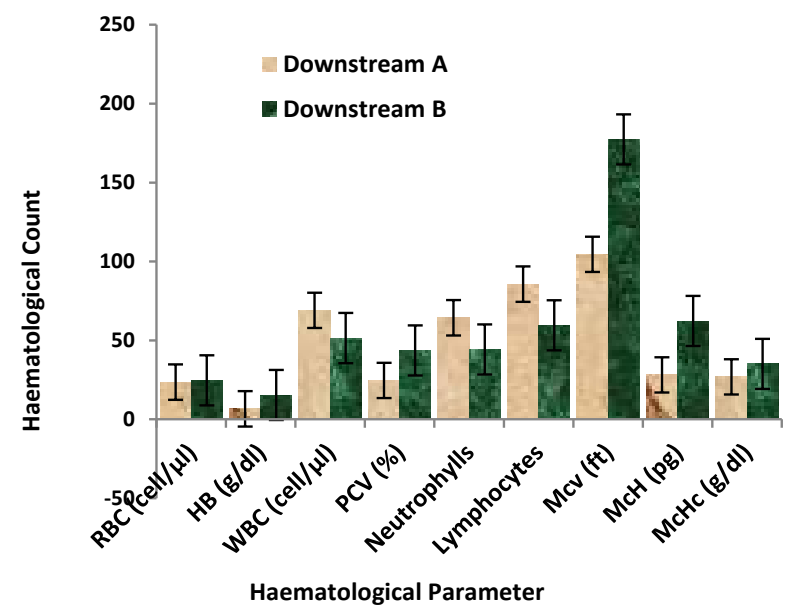

Figure 2: Spatial variation in the haematological profile of C. buthupogon from Asa River.

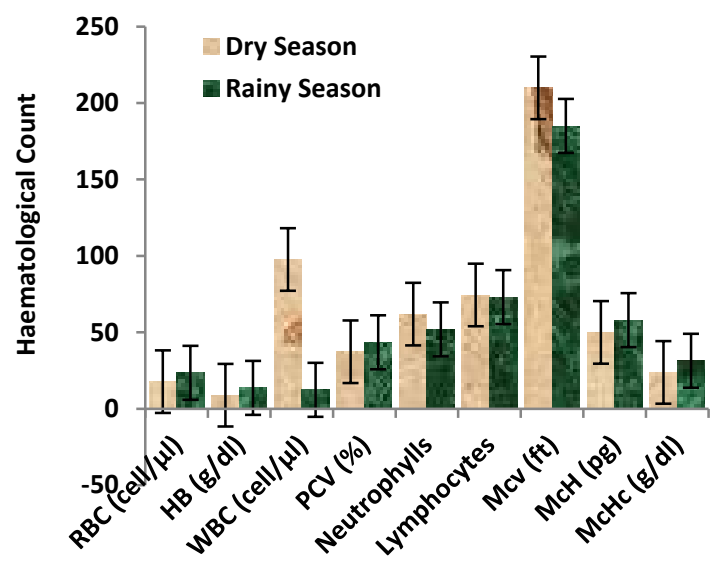

Haematological Parameters

Figure 3: Seasonal variation in the haematological profile of $H$. longifilis from Asa River.

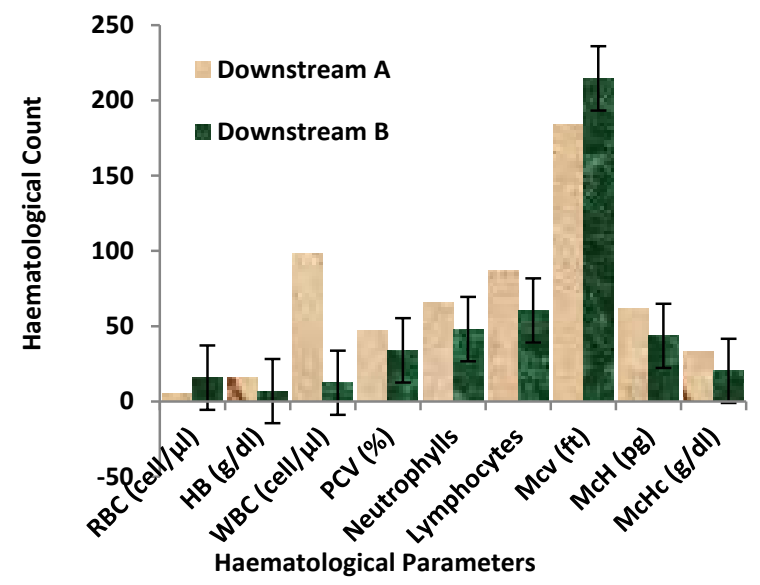

Figure 4: Spatial variation in the haematological profile of H. longifilis from Asa River.

as compared to dry season. A highly significant enhancement in W.B.C. was also observed in dry season as compared to rainy season. The results of red cell indices viz., $\mathrm{MCV}, \mathrm{MCH}$ and $\mathrm{MCHC}$ revealed significant increase $(\mathrm{p}<0.001)$ in rainy season as compared to dry season. The results of ANOVA revealed a significant seasonal effect on RBC $(p<0.05)$, WBC $(p<0.001)$, $\mathrm{Hb}(\mathrm{p}<0.01), \mathrm{PCV}(\mathrm{p}<0.001)$. The results of the red cell indices showed a highly significant $(\mathrm{p}<0.001)$ seasonal effect in MCV and MCHC. Studies have shown that the seasonal changes affect the water quality and the fishes being aquatic organism, its physiology is greatly affected by the aquatic environment (water) which internals influenced by the seasonal changes. Blood cell responses are important indicators of changes in the internal and/or external environment of animals. Water quality cans thus be regarded as one of the major factors responsible for individual variations in fish haematology. Figures 5-8 revealed the biochemical responses of the two-sampled fish to the polluting water body. Blood plasma was analyzed for various biochemical parameters viz; total Protein, glucose, cholesterol, albumin, chloride, hydrogen carbonate, potassium, sodium and calcium. Significant change was observed in the biochemical parameters in the blood of the two fish species examined in this present study. There was a decline in the blood plasma protein content during the dry season and at the upstream sit of the river. The cholesterol level likewise decreased and increased in the same manner as the plasma protein. Blood glucose content decreased markedly from dry to rainy seasons and the highly polluted upstream recorded high value compared to low value recorded for the downstream. Potassium, sodium, calcium, albumin, chloride and hydrogen carbonate increased from dry to rainy season and was equally found to increase in values from upstream to downstream. In this study blood serum components (LDH, ALP, ALT) analysis revealed obvious significant differences $(\mathrm{P}<0.05)$, and their value decrease from upstream to downstream and from rainy to dry season.

Haematological indices are very important parameters used in the evaluation of fish physiolog ical status (Ogundiran, 2007; Adewoye, 2010 and Yekeen and Fawole, 2011). A decrease in 


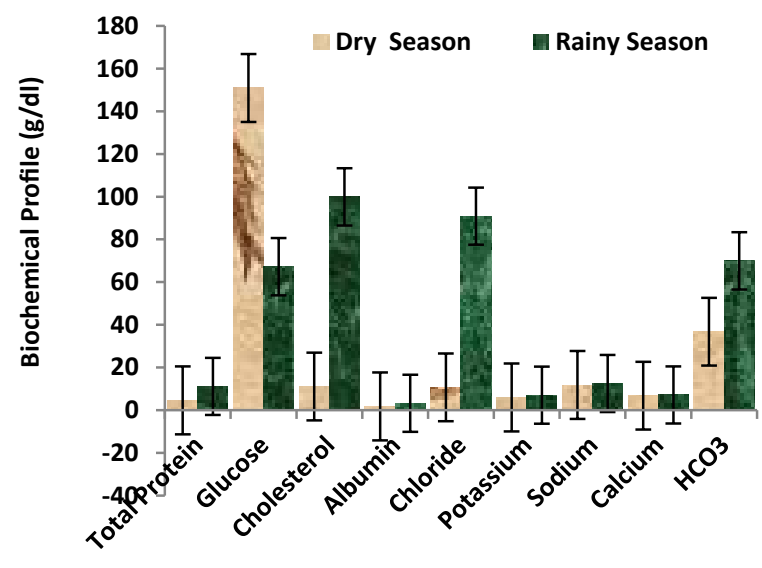

Biochemical Parameter

Figure 5: Seasonal variation in the biochemical profile of C. buthupogon from Asa River.

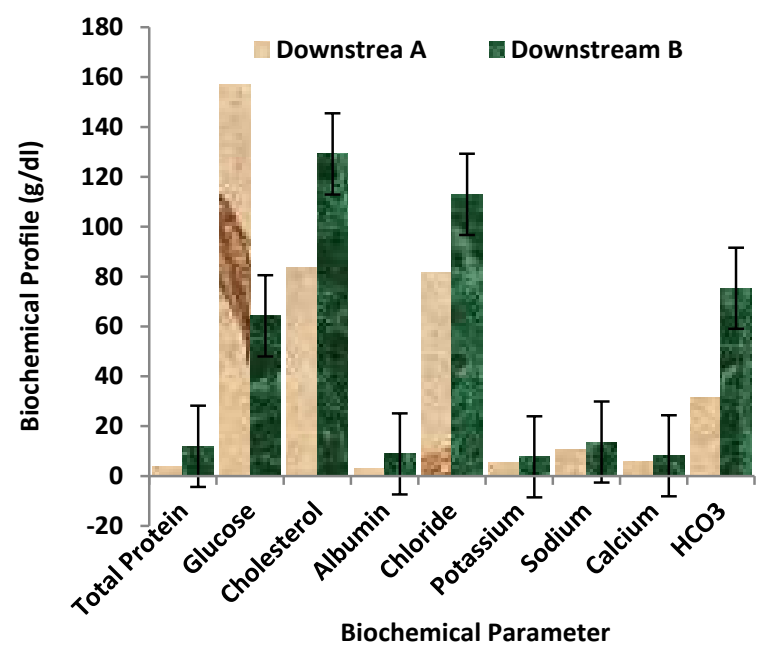

Figure 6: Spatial variation in the biochemical profile of C. buthupogon from Asa River.

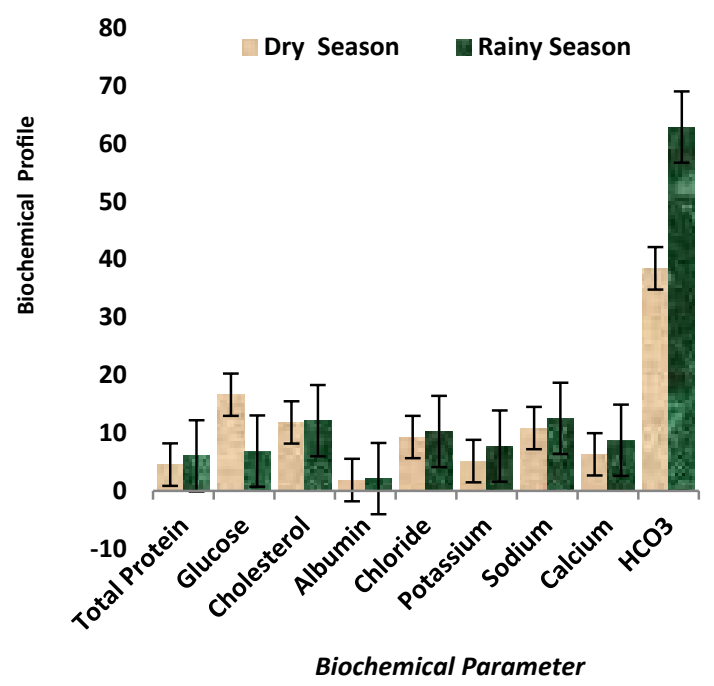

Figure 7: Seasonal variation in the biochemical profile of H. longifilis from Asa River.

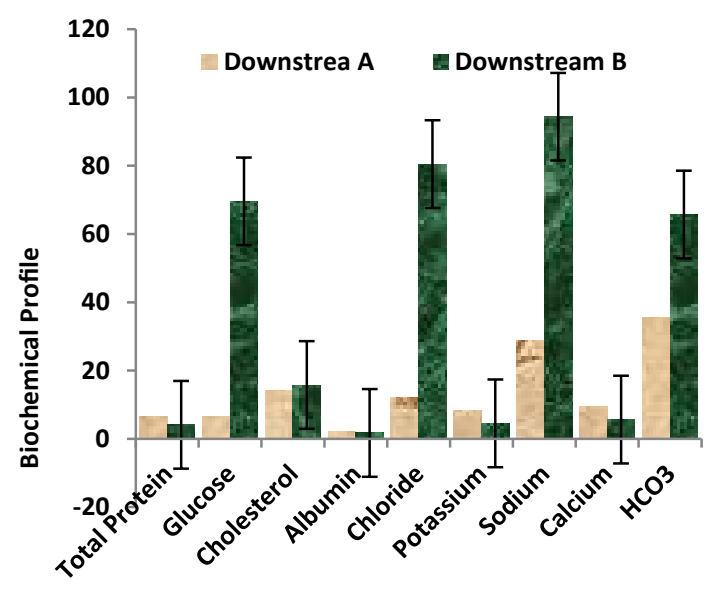

Biochemical Parameter

Figure 8: Spatial variation in the biochemical profile of H. longifilis from Asa River.

the value of RBC (Erythrocyte count) and in the percentages of PCV (Haematocrit) in this study indicated a worsen state of an organism's condition and its developing anemia. Decrease in the concentration of haemoglobin in the blood, which may be linked to the effects of toxic metals on blood, as well as decrease in oxygen may also indicate anemia or confirm negative changes occurring in fish species used in this work. An increase in the WBC (Leucocytes count) is mostly observed during the initial stage of stress reaction when fish tries to restore disturbed homeostasis, however later, a decrease of leucocytes count can be observed, which shows the weakening of immune system on the basis of haematological studies, it would be possible to forecast the physiological state of fish in natural water bodies (Adeyemo et al., 2003 and Ogundiran et al., 2007). The count of RBC was quite a stable index and the fish body attempt to maintain this count within the limits of certain physiological standards using various physiological mechanisms of compensation. Haemoglobin concentration reflects the supply of an organism with oxygen and the organism itself attempts to maintain the oxygen level as much stable as possible. Therefore, all hematological indices can be secondary responses of an organism to pollutant/irritants or changing environment.

Among analyzed haematological indices, RBC, HB, PCV values were found to be lower in the dry season and slightly high in the rainy season and, the same trend was also observed in the upstream and downstream sites of the river; this may be due to an inhibited RBC production in the haematopoetic organs and or may be linked to impaired haemoglobin synthesis. Ambient toxicant might have been responsible for disintegration of RBC cells, which in turn have caused reduction of haemoglobin and PCV (haematocrit) count. This confirmed an anemic condition in the blood sample of the two examined fish species; Anaemia of this magnitude is characterized by the reduction in the RBC count, PVC percentage and haemoglobin contents which have also been reported by several workers after heavy metal exposure (Adeyemo et al., 2003 and Ogundiran, et al., 2007). Existing data 
on the effects of pollutants on RBC indicated that pollutants like insecticide and industrial effluents have affinity for the blood stream, which produced a number of abnormalities in the blood (Adewoye, 2010 and Yekeen and Fawole, 2011). Pollutants like insecticides have the capacity to penetrate into the RBC (Yekeen and Fawole, 2011), this was reported to have induced the formation of anti-erythrocyte antibodies. The reasons for decrease in erythrocytes from the blood may be extravasations, a plastic anaemia or immunohaemolytic anaemia.

Slightly increased level of Mean Cell Volume (MCV), Mean Cell Heamoglobin (MCH) and Mean Cell Heamoglobin Concentration (MCHC) value was evident in this work and this is an indication that anaemia produced, is of macrocytic hypochromatic type. MCHC is a good indicator of red blood cell swelling (Wepener et al., 1992 a \& b). The MCHC is not in any way influenced by the blood volume or by the number of cells in the blood but can be interpreted incorrectly only when new cells with different haemoglobin concentrations, are released into blood circulation (Adewoye, 2010). The significant decrease in the value of $\mathrm{MCHC}$ at upstream and in the rainy season may probably be attributed to red blood cell swelling. In another instance, a significant decline in the values of $\mathrm{MCH}$ and $\mathrm{MCHC}$ have also been reported by khahak and Hafeez (1996) in fish, Cryprinion watsoni exposed to extensively used agriculture pesticides malathion. A drop in the MCHC value was also reported by Qurestii et al., (1995) in fish, Cryprinion Watson after exposure to various stresses like hypoxia, anaemia and hyperthermia. A significant decrease in haematological parameters other than WBC have also been documented by Sampath et al., (1993) and Omoregie et al., (1994) when fish are exposed to polluted environment under laboratory conditions; the anaemic effects reported here could be due to destruction of erythrocytes or the inhibition of erythrocyte production (Omoregie et al., 1994) and haemodilution (Sampath et al., 1993).

Changes in the WBC and RBC in fish have been reported to be a strong indicator of stress due to the presence of toxicants in the aquatic environment. WBC count increased at upstream location of Asa River compared to the downstream and this may be an indication of high pollution load recorded upstream. Also, during the dry season, WBC was noticed to be very high compared to the rainy season when the volume of water became high; this is perhaps, a typical defensive response of the fish against a high toxic invasion. Both leucopenia and conversely leukocytosis (increased number of WBC) have been submitted in fish populations exposed to heavy metals (Ogundiran, et al., 2007). In this present study, the percentage of PCV was lower for upstream and dry season where pollution load was high. Generally, WBC abundance provides an indication of fish health and a high WBC count may indicate a sub-clinical infection.

Generally, blood is one of the most sensitive indicators of much metabolic disorderliness occurring in the body, therefore, blood test play a key role in the easy and rapid diagnosis of ailments occurring in the animal body. In the present investigation, plasma protein level decreased in both species examined from dry season to rainy season, and from upstream to downstream, when and where the pollution index were noticed to be high respectively. The decreased protein level is an indication of hyper protein anaemia; which can be correlated with the possible inhibition of protein synthesis occurring in the body. However, nutritional imbalances, infection due to high chemical pollutants noticed upstream and in the dry season, kidney damage or inanition (i.e. condition of exhaustion caused by a lack of nutrients in the blood) due to pollution could be the other possible reasons. Reduction in the value of protein could also be due to inhibition of RNA synthesis or proteolytic activities. When the energy demand of the body is very light such that energy derived from glucogenesis and glycogenolysis are not enough, more energy may be obtained through synthesis of glucose from non-carbohydrate sources including protein (Gluconeogenesis). This will lead to a reduction in the level of protein which may eventually lead to emaciation in exposed fish species. Such reduction in protein due to exposure to toxicant had been reported in fishes (Maruthanayagam and Shormila, 2004). Low plasma protein in effluent exposed fish species was also recorded in a similar study and it was correlated to possible nutritional imbalance, infections disease, kidney damage or lack of nutrients in the blood, due to the polluted nature of the environment. In another study, the toxic effects of heavy metals like copper and zinc, and their mixture were studied on some selected blood biochemical parameters in common carp, Cyprinus carpio at sub lethal level over a period of 30 days, and it was submitted that, total serum protein were decreased significantly (Dhanapakian and Ramasamy, 2001). Similarly, sunfish populations (Lepomis spp.) inhabiting selenium-laden coal in the effluent polluted water body showed a significantly lower plasma protein levels and were correlated with possible nutritional stress and disease (Lohner et al., 2001c). However, Dethloff et al., (2001) reported wild rainbow trout from a creek receiving runoff from a copper mine with total protein remained unaffected in another investigation, the effects of petroleum hydrocarbons on two marine fish species winter flounder, Pseudopleuronectes americanus and Atlantic cod, Gadus morhua was carried out and a significant decreased in total protein were reported (Kham, 1987) which is in conformity with the findings in the present study. Also, Sheriff et al., (2001) submitted a significant increase in total blood protein after feeding copper to Javanese Carp, Puntius gonionotus (Bleeker). Van vuren et al., (1994) reported an increase in blood protein (hyperprotenaemia) in fish, Clarias gariepinus exposed to copper and this was not in agreement with the observation recorded in this present study. Meanwhile Indian major carp, Labeo rohita exposed to pesticides, cypermethrin while glucose level was found at an elevated level (sheriff et al., 2001).

Glucose is one of the highly sensitive features of stress nature of an organism; its high concentration in blood plasma of the two fish species caught from upstream and in the dry season in this study, indicated that the fish is in stress and it is intensively using its energy reserves (i.e. glycogen in liver and muscles). Meanwhile, a decrease in concentration observed indicates the exhaustion of 
energy (glycogen) resources and subsequently, the worsening of an organism status. A decrease in glucose in blood plasma was observed in a long-term exposure to heavy metals (Vosyliene, 1999 a, b). The above submission can better support the results in this present investigation and an increase in the glucose level in the blood plasma of the two fish species, both at upstream and dry season, conformed to the general studies worldwide. Increased glucose level in fish species at upstream and in the dry season reflected hyperglycemia, while decrease in the downstream and in the rainy season, reflected hypoglycemia and these may be attributed to high and low level of pollution at upstream, dry season and downstream and rainy season respectively. Generally, both the conditions of different response of plasma glucose confirmed the presence of ailment in the fish species, a condition that may be the resultant effects of pollution. Hyperglycemic conditions developed either due to increased glycogenolysis or decrease in glucose utilization by the cell, which means the inhibition of glycolysis. It has been suggested that the mechanism behind the induction of hyperglycemia is the activation of sympathetic nervous system, which resulted in the release of adrenaline from adrenal medulla. Adrenaline then stimulated the pituitary to produce greater amount of ACTH which in turn activated the adrenal cortex to secrete more glucocorticoid hormones which are responsible for increased glucose production from liver with the consequent release into the blood (Sreenivasan, and Moorthy, 2011). Fox and Virgo (1986a) concluded that Dieldrin affects hyperglycemia by stimulating the lateral hypothalamus, thus increasing the cholinergic and alphaI-adrenergic stimulation of the pancreas. This would result in an increased release of glucagon and decreased secretion of insulin with the development of hyperglycemia (Maruthanayagam and Shormila, 2004). The different variations of plasma glucose recorded across the sample locations and the two seasons of the year. The decrease in glucose content observed in this work most especially at the downstream portion of the river and during the rainy season of the year may probably be related to increased glucose utilization required for the induction of liver enzymes and microsomal protein under fair environmental stability. Similarly, in a laboratory study where rainbow trout, Oncorhynchus mykiss exposed to sublethal concentrations of $\mathrm{Cu}(14 \mu \mathrm{g} / \mathrm{l})$ and Zinc (57 and $81 \mu \mathrm{g} / \mathrm{l}$ ) showed an increase in plasma glucose (Dethloff et al., 1999). Also, common Carp, Cyprinus Carpio treated with copper sulphate $\left(\mathrm{CuSO}_{4}\right)$, paraquat and methidalthion exhibited increased blood glucose level (Aszlalos et al., 1990). In another study, the effects of heavy metal mixtures like $\mathrm{Cu}$ and $\mathrm{Zn}$ were studied on some blood biochemical parameters in fish at sublethal level over the period of 30 days, serum glucose were decreased significantly (Dhanapakiam and Ramasamy, 2001). Van Vuren et al., (1994) also reported an increase in blood glucose (hyperglycemia) in fish, Clarias gariepinus exposed to $\mathrm{Cu}$, after 2-hours of exposure, the count of glucose increased in the blood of Carp (Nemscok, et al., 1985). An increase in glucose count was observed only after acute exposure to copper (Vosyliene, 1996b). An increase in glucose concentration was also observed in various fish species after their 15-day exposure to $10 \mathrm{mg} / 1$ of hexavalent chromium Exposure to water from lower Rhine River induced a stress response by increasing glucose level in Rainbow trout (Nolan et al., 2003).

Like total protein, cholesterol also decreased significantly in both the grossly polluted location and in the dry season when polluted load was high and the resultant effects is termed hypocholesterolaemia. High cholesterol in the serum of the two fish species showed high lipid content in the blood. Changes in blood cholesterol level are related to changes caused by the action of chemical pollutants in the river in the permeability of hepatic cells (Yousef et al., 2003). Accumulation of pollutants in the liver is reported to disrupt lipid metabolism and increase serum cholesterol level (Yousef et al., 2003; Kalender et al., 2005). The decrease in cholesterol level recorded in the present investigation may be linked to the lack or low availability of starting material acetyl-CoA for cholesterol synthesis in the absence of glucose utilization and dependence of body on alternate energy source (gluconeogenesis). Considerably, variation was found in serum cholesterol and protein contents after insecticide feeding to a freshwater fish, Clarias batrachus. Folmar (1993) noted significantly lower serum cholesterol and was thought to be associated with the chronic stress of being in an environment contaminated with chlorinated pesticides, PCBs and heavy metals. There was no significant difference in the value of albumin while there were significant correlations for chloride, potassium, sodium, calcium and hydrogen carbonate for both sampling sites and the two seasons of the year.

Tables 1 and 2 showed the serum activities of the two bioindicators species studied in this work and an increased activity of AST, ALT, ALP and LDH in the plasma of C. Buthupogon and $H$. longifilis indicate that long-term exposure to chemical pollutant causes tissue damage in fish and this has also been reported in O. mykiss and Channa punctatus, exposed to diazinon and monocrotophos respectively (Banaee et al., 2011). The plasma activity of this serum indices helps to determine tissue damage in

Table 1: Blood Serum Enzyme response of the fish Species to Water pollution (Season).

\begin{tabular}{|c|c|c|c|c|}
\hline \multirow{2}{*}{ Parameter/Season } & \multicolumn{2}{|c|}{ Clarias buthupogon } & \multicolumn{2}{|c|}{ Heterobranchus longifilis } \\
\hline & Rainy Season & Dry Season & Rainy Season & Dry Season \\
\hline AST $\left(\mu\right.$ kat $\left.\mathbf{I}^{-1}\right)$ & $139.65 \pm 44.01$ & $87.23 \pm 38.19^{a}$ & $156.21 \pm 69.00$ & $109.11 \pm 21.22^{\mathrm{a}}$ \\
\hline ALT $\left(\mu\right.$ kat $\left.\mathbf{l}^{-1}\right)$ & $9.28 \pm 1.23$ & $4.00 \pm 1.21^{\mathrm{b}}$ & $11.21 \pm 0.11$ & $7.29 \pm 1.10^{\mathrm{b}}$ \\
\hline $\operatorname{ALP}\left(\mu\right.$ kat $\left.^{-1}\right)$ & $209.65 \pm 32.69$ & $265.03 \pm 7.09^{b}$ & $239.71 \pm 70.34$ & $297.34 \pm 89.23^{\mathrm{a}}$ \\
\hline LDH $\left(\mu\right.$ kat l $\left.^{-1}\right)$ & $926.99 \pm 77.90$ & $876.23 \pm 65.56^{\mathrm{a}}$ & $877.11 \pm 71.71$ & $997.38 \pm 65.70^{\mathrm{a}}$ \\
\hline
\end{tabular}

$\mathrm{a}=$ Significant differences $(\mathrm{P}<0.05)$ with control group; $\mathrm{b}=$ Non- significant differences $(\mathrm{P}>0.05)$ with control group;

$\mathrm{AST}=$ Aspartate transeaminase; $\mathrm{ALT}=\mathrm{Alkaline}$ transeaminase; $\mathrm{ALP}=$ Alkaline phosphatase; $\mathrm{LDH}=\mathrm{Lactate}$ dehydrogenase. 
Table 2: Blood Serum Enzyme response of the fish Species to Water pollution (Location).

\begin{tabular}{|c|c|c|c|c|}
\hline \multirow{2}{*}{ Parameter/Season } & \multicolumn{2}{|c|}{ Clarias buthupogon } & \multicolumn{2}{|c|}{ Heterobranchus longifilis } \\
\hline & Upstream & Downstream & Upstream & Downstream \\
\hline $\operatorname{AST}\left(\mu\right.$ kat l $\left.^{-1}\right)$ & $109 \pm 22.21$ & $65.28 \pm 11.23^{\mathrm{a}}$ & $121.00 \pm 12.11$ & $139.00 \pm 61.44^{\mathrm{a}}$ \\
\hline $\operatorname{ALT}\left(\mu\right.$ kat $\left.^{-1}\right)$ & $11.02 \pm 1.33$ & $7.88 \pm 3.21^{\mathrm{b}}$ & $6.99 \pm 6.12$ & $9.76 \pm 2.03^{\mathrm{b}}$ \\
\hline $\operatorname{ALP}\left(\mu\right.$ kat $\left.^{-1}\right)$ & $222.45 \pm 21.90$ & $278.01 \pm 9.18^{b}$ & $298.34 \pm 66.00$ & $298.41 \pm 44.38^{a}$ \\
\hline LDH $\left(\mu\right.$ kat I $\left.^{-1}\right)$ & $976.11 \pm 22.09$ & $902.77 \pm 56.56^{\mathrm{a}}$ & $821.22 \pm 81.92$ & $921.11 \pm 66.21^{\mathrm{a}}$ \\
\hline
\end{tabular}

$\mathrm{a}=$ Significant differences $(\mathrm{P}<0.05)$ with control group; $\mathrm{b}=$ Non- significant differences $(\mathrm{P}>0.05)$ with control group;

$\mathrm{AST}=$ Aspartate transeaminase; $\mathrm{ALT}=$ Alkaline transeaminase; $\mathrm{ALP}=$ Alkaline phosphatase; $\mathrm{LDH}=\mathrm{Lactate}$ dehydrogenase .

fish and this study has revealed that water pollution has a direct impact on the serum activities of the blood.

Conclusively, the toxic effects of water pollution in fish have been demonstrated in the present study and it was established that pollutants in water could be moderately toxic to aquatic faunas. Therefore, it was proven that the use of the selected biochemical markers and chemical analyses has been a suitable tool to monitor the level of contamination of aquatic environment.

\section{References}

Asztalos, B., Memcsok, J., Brenedeczky, I., Gabriel, R., Szabo, A. (1990) The effects of Pesticide on some biochemical parameters of carp (Cyprinus carpio). Arch Environ Contam. Toxicol 19, 275-282.

Banaee, M., Sureda, A., Mirvaghefi, A.R., Ahmadi, K. (2011) Effects of diazinon on biochemical parameters of blood $n$ rainbow trout (Oncorhynchus mykiss). Pest Biochem Physiol 99, 1-6.

Ramona, A., Biawas, A.K., Kundu, S., Saha, A.K., Yadav, R.B.R. (2001) Efficacy of distillery effluent on seed germination and seedling growth in mustard, cauliflower and radish. Proc Nat Acad Sci 71, 129-135.

Censi, P., Spoto, S.E., Saiano, F., Sprovieri, M., Mazzola, S. et al. (2006) Heavy metals in coastal water systems: A case study from the northwestern Gulf of Thailand. Chemosphere 64, 1167-1176.

Riba, I., Conradi, M., Forja, J.M., DelValls, T.A. (2004) Sediment quality in the Guadalquivir estuary: Lethal effects associated with the Aznalcollar mining spill. Mar Pollut Bull 48, 144-152.

Pimpao, C.I., Zampronio, A.R., Silva de Assis, H.C. (2007) Effects of deltamethrin on hematological parameters and enzymatic activity in Ancistrus multispinis (Pisces, Teleostei). Pest Biochem Phsiol 88, 122-127.

Rios, F.S., Kalini, A.L., Rantin, F.T. (2002) The effect of long term food deprivation on respiration and hematology of the neotropical; fish, Hoplias malabaricus. J Fish Biol 61, 85-95.

Elahee, K.B., Bhagwant, S. (2007) Hematological and gill histopathological parameters of three tropical fish species from a polluted lagoon on the west coast of Mauritius. Ecotoxicol Environ Saf 68, 361-71.
Ashraf, W. (2005) Accumulation of heavy metals in kidney and heart tissues of Epinephelus microdon fish from the Arabian Gulf. Environ Monit Assess 101, 311-316.

Kori-Siakpere, O., Ake, J.E.G., Idoye, F. (2005) Hematological characteristics of the African snakehead, Parachanana obescura. Afr J Biotech 4, 527-530.

Houston, J.B., Carlile, D.J. (1997) Incorporation of in vitro drug metabolism data in physiologically based pharmacokinetic models. Toxicol In Vitro, 11, 473-478.

Rizkalla, E.H., Abd El -Haleem, M.E., Shalaby, A.M.E. (1999) Haematological changes in Cyprinus carpio L. as a result of short and long term exposure to different combinations of copper, cadmium and zinc. Egypt J Aquat Biol Fish 175-193.

Sreenivasan, R.S., Moorthy, K.P (2011) Biochemical stress of chromium in tannery effluents on the fresh water fish, Tilapia mossambica (Pisces). Int J Biol Med Res 2, 616-620.

Kocabatmaz, M.H., Ekngen, G. (1982) Degipik tur baliklarda Kan ornegi alinmasi ve hematolojik metottlarin standardizasyonu. Doga Bilimeler Dergisi, 2, 149-159.

Adewoye, S.O. (2010): Haematological and biochemical changes in Clarias gariepinus exposed to Trephosia vogelii extract. Advances in Applied Science Res 1, 74-79.

Yekeen, T.A. and Fawole, O.O. (2011) Toxic Effects of Endosulfan on Haematological and Biochemical Indices of Clarias gariepinus. African J Biotechnol 10, 14090-14096.

Adeyemo, A.O., Agbede, S.A., Taiwo, V.O., Adedeji, B.O. (2003) Prevalence, abundance and intensity of Clinostomumilapiae on cultured Oreoch omis niloticus. Tropical Vetenarian 21, 129-133.

Khattak, I.U.D., Hafeez, M.A. (1996) Effect of malathion on blood parameters of the fish, Cyprinion watsoni, Pak J Zool 28, 45-49.

Blaxhall, P.C. (1972) The hematological assessment of the health of freshwater fish: a review of selected literature $\mathrm{J}$ fish Biol 4, 953-604.

Dacie, J.C., Lewis. S.M. (2001) Practical Haematology. Churchill Livingstone, London.

Dethloff, G.M., Bailey, H.C., Maier, K.J. (2001) Effects of dissolved copper on selected hematological, biochemical and 
immunological parameters of wild rainbow trout (Oncorhynchus mykiss). Arch Environ Contam Toxicol 30, 371-380.

Dhanapakiam, P., Ramasamy, V. K. (2001) Toxic effects of copper and zinc mixture on some hematological and biochemical parameters in common carp, Cyprinus carpio

(Linn) J environ Biol 22, 105-111.

Folmar, L.C. (1993) Effects of chemical contaminat on blood chemistry of teleost fish. A bibliography and synopsis of selected effects. Environ Toxicol Chem 12, 337-335.

Fox G.R., Virgo, B.B. (1986a) Prevalence of hyperglycemia to dieldrin toxicity in suckling and adult rats. Toxicol 38, 315-326.

Kalender Y., Kalender S., Ogutcu A., Uzunhisarcikli M., Durak D. (2005) Diazinon-induced hepatotoxicity and protective effect of Vitamin E on some biochemical indices and ultrastructural changes. Toxicol 211, 197-206.

Khan, R.A. (1987) Effects of chronic exposure to petroleum hydrocarbons on two species of marine fish infected with a hemoprotozoan. Trypanosoma murmanensis. Canadian J Zool 65, 2703-2709.

Lohner, T.W., Reash, R.J., Willet, V.E., Fletcher, J. (2001c) assessment of tolerant sunfish populations (Lepomis sp) inhabiting selenium-laden coal ash effluents. serum chemistry and fish health indicators. Ecotoxicol. Environ Safe 50, 225-232.

Maruthanayagam, C., Sharmilla, G. (2004) HaematoBiochemical variations induced by the pesticide, monocrotophos in Cyprinus carpion during the exposure and recovery periods. Nat Environment and Poll Tech 3, 491-494.

Nemscok, J., Orban, L., Vic, E., Asztalos, B., Boross, L. (1985): Effect of $\mathrm{Cu}$ on some biochemical parameters of fishes. Symp. Biol Hung 19, 413- 425.

Nolan, D.T., Spanings, F.A., Ruane, N.M., Hadderingh, R.H., Jenner, H.A., et al. (2003) Exposure to water from the lower Rhyne induces a stress response in the rainbow trout. Oneorhychus mykiss. Arch Environ Contam Toxicol 45, 247-257.
Ogundiran, M.A., Fawole, O.O., Adewoye, S.O. (2007) Effects of soap and detergent effluents on the haematological profiles of Clarias gariepinus. Science focus 12, 84-88.

Omoregie, E., Eseyin, T.G., Ofojekwu, P.C. (1994) Chronic effects of formalin on erythrocyte counts and plasma glucose of Nile tilapia, Oreochromis niloticus. Asian Fisheries Sci 7, 1-6.

Qurestti, I.Z., Hafeez. M.A., Sheikh, S.A. (1995) Hwmatological responses of the fish. Cyprinion waisoni, to hypoxia, anemia and hyperthermia. Pakistan J Zool 27, 219-227.

Sheriff, M., Jayawardena, P.A., Yusoff, F.M., Subasinghf, R. (2001) Immunological parameters of Jvanese carp. Puntitus gonionotus (Bleeker) exposed to copper and challenged with Aeromonas hydrophila. Fish shellfish immunol 11, 281-291.

Van Vuren, J.H.J., Van Der Merwe, M., Du Preez, H.H. (1994) The effects of copper on the blood chemistry of Clarias gariepinus (Clariidae). Ecotoxicol Environ Saf 29, 187-199.

Vosyliene, M.Z. (1996b) The effect of long-term exposure to copper on physiological parameters of rainbow trout. (Oncorhynchus mykiss). Studies of haematological parameters. Ekologija, 1, 3-6.

Wepener, V., Van Vuren J.H.J., Du Preez, H.H. (1992a): The effect of iron and manganese at an acidic $\mathrm{pH}$ on the hematology of the banded tilapia (Tilapia sparrmanii Smith). Bull Environ Contam Toxicol 49, 613-619.

Wepener, V., Van Vuren. J.H., Preez, H.H. (1992b) The effect of hexavalent chromium at different $\mathrm{pH}$ values on the haematology of Tilapia sparmani (Cichlidae). Comp Biochem Physiol 101, 375-381.

Yousef, M.I., El-Demerdash, F.M., Kamel, K.I., Al-Salhen, K.S. (2003) Changes in some haematological and biochemical indices of rabbits induced by isoflavones and cypermethrin. Toxicol 189, 223-234. 